Henning Andersen

University of California, Los Angeles

\title{
The Western South Slavic Contrast Sn. sah-ni-ti II SC sah-nu-ti
}

Prispevek na novo ocenjuje tradicionalno razlago za »svojevrsten razvoj« praslovanskih glagolov II. razreda $\mathrm{z}$ aoristno in/ali nedoločniško pripono -no-, ki so izpričani v scsl. kot szxnoti 'sahniti', pol. schnać, rus. soxnut', sh. sahnuti, vendar v sln. kot sahniti. Namesto da bi izhajal iz domneve, da je pripona -ni-izpodrinila -no-, avtor dokazuje, da je smiselno izhajati iz praslovanske razlike -no- \| -ny- (< zgodnjepraslovansko inovativno $*_{-} n \bar{u}-n$ - $\|$ arhaično $\left.*_{-} n \bar{u}-\right)$, ki je po vsej verjetnosti iz časa pred slovanskimi selitvami. Ta razlika je potovala s Slovani, ki so poselili zahodnojužnoslovanska in zahodnoslovanska področja med 5. in 8. stoletjem, zaradi nje pa je v naslednjih stoletjih nastalo tekmovanje med dvema različnima jezikovnima oblikama.

The paper reexamines the traditional explanation for the "idiosyncratic development" of the Common Slavic Class II verbs with the aorist and/or infinitive suffix -no-, attested in OCS szxnǫti 'dry', P schnać, R soxnut', SC sahnuti, but in Slovenian as sahniti. Rather than proceeding from the assumption that the -no- type was replaced by -ni-, the author demonstrates that is reasonable to depart from a Common Slavic dialect difference $-n o-\| 1-n y-(<$ Early Common Slavic innovative $*_{-} n \bar{u}-n$ - $\|$ archaic $\left.*_{-} n \bar{u}-\right)$, which probably had its origin in the period before the Slavic Migrations. This variation was transported with the Slavs who colonized the Western South Slavic and West Slavic territories in the 400-700s and in turn gave rise to sociolinguistic competition between the alternatives in the following centuries.

\subsection{Introduction}

Slovenian stands out among the Slavic standard languages by its peculiar reflexes of the Common Slavic Class II verbs. Other modern Slavic languages have verbs that correspond directly to the Old Church Slavonic (and Common Slavic) conjugation type with the aorist and/or infinitive suffix -no-, e.g., OCS sbxnoti 'dry', P schnać, R soxnut', SC sahnuti, etc. But Slovenian shows an idiosyncratic development of $*_{-n}$ - - to -niin the infinitive stem (so Priestly 1993: 419), cf. Sn. sahniti dry; see figure 1. ${ }^{1}$

Figure 1. The conjugation of $-n i$ - and $-i$ - verbs in Slovenian and Serbo-Croatian

\begin{tabular}{|c|c|c|c|c|}
\hline & \multicolumn{2}{|c|}{ Verbs in $-n i-\|-n u-$} & \multicolumn{2}{|c|}{ Verbs in $-i-\| l-i-$} \\
\hline & Slovenian & Serbo-Croatian & Slovenian & Serbo-Croatian \\
\hline Pres. 1sg. & $s a h-n-e-m$ & $s a h-n-\bar{e}-m$ & bran- $-i-m$ & bran- $\bar{l}-m$ \\
\hline Pres. 3pl. & sah-n-ej-o & $s a h-n-\bar{u}$ & bran-ij-o & bran-ēe \\
\hline Pres. ptcpl. & $s a h-n-o \check{c}$ & $s a h-n \bar{u}-c ́ i$ & bran-e-č & bran- $\bar{e}-c i$ \\
\hline Impv. & $s a h-n-i$ & $s a h-n-i$ & bran- $i$ & bran-i \\
\hline Inf. & sah-ni-ti & $s a h-n u-t i$ & bran-i-ti & bran-i-ti \\
\hline$l$-form & sah-ni-l & sah-nu-o & bran-i-l & bran-i-o \\
\hline Past ptcpl. & $s a h-n i-v \check{s} i$ & $(u-) s a h-n \bar{u}-v s ̌ i$ & bran-i-vši & bran-i-vši \\
\hline Past pass. ptcpl. & $(u-) s a h-n j-e n-\phi$ & $(u-) s a h-n \bar{u}-t-\phi$ & branj-en- $\phi$ & branj-en- $\varnothing$ \\
\hline
\end{tabular}

\footnotetext{
${ }^{1}$ The research reported in this paper was first presented at a symposium on "Dialectology
} 
This peculiarity, of course, has been noted long ago, and the "idiosyncratic development" that gave rise to it has been explained as a simple analogy with the verbs of Class IV, e.g., braniti 'defend'. But perhaps because of the simplicity of this explanation this unique change has rarely been viewed in a perspective that would allow its integration into a wider context of Slavic diachronic linguistics. In fact, as I aim to show in this paper, it is only recently that it has become possible to examine and account for it in such a perspective.

In the following pages, after a preliminary definition of its Common Slavic background, I will characterize the problem that is posed by the modern Slovenian conjugational type of sahniti by reviewing the most recent relevant scholarship on the topic (section 1). Next I will restate the "idiosyncratic development" and show how it fits in with data from other Slavic languages (section 2). Finally I will demonstrate how this hypothetical, wider perspective is justified and suggest that it is appropriate to apply it also to other Slavic data (section 3). ${ }^{2}$

\subsection{Leskien's Classes II and IV}

In August Leskien's classification, the Common Slavic Class II defines thematic verbs with a present tense formed with the suffix $*-n-e / o-$. Two subclasses are distinguished, subclass II.1, which comprises only the verb stati 'stand up', and subclass II.2, verbs that have an infinitive stem formed with the suffix *-no-. These, in turn, fall into two subtypes, verbs with a vocalic root and nasal suffixes in all forms (minoti 'pass', II. 2.a) and verbs with a consonantal root and nasal suffixes only in the present tense, in the other parts of the paradigm that are built on the present tense stem, and in the infinitive (dvignoti 'move', II.2.b); see Leskien 1910 [1990]: 149-52, Vaillant 1966: 223-60; cf. figure 2 . $^{3}$

and Historical Linguistics. Contributions of South Slavic," University of California, Berkeley, Ca., 22 April 1995. It was carried out with support from the UCLA Academic Senate Council on Research and from the John Simon Guggenheim Memorial Foundation.

${ }^{2}$ The following abbreviations are used in this paper: aor. (aorist), Bg. (Bulgarian), Cz. (Czech), CS (Common Slavic), d. (dialectal), ECS (Early Common Slavic), impf. (imperfect), impv. (imperative), inf. (infinitive), LCS (Late Common Slavic), M (Macedonian), o. (old, obsolete), OCS (Old Church Slavonic), P (Polish), pass. (passive), Pb. (Polabian), pl. (plural), p.p.p. (past pass. ptcpl.), pres. (present tense), PS (Proto-Slavic), ptcpl. (participle), R (Russian), res. (resultative), SC (Serbo-Croatian), sg. (singular), Sn. (Slovenian), st. (standard), US (Upper Sorbian).

Note especially that CS (Common Slavic), refers to the prehistorical development of Slavic, ECS (Early Common Slavic), to the period before the $* \bar{u}>* \bar{y}$ change, and LCS (Late Common Slavic), to the period between the qualitative differentiation of inherited long and short vowels and the Jer-Shift. PS (Proto-Slavic) labels the reconstructed segments and wordforms that serve as point of departure in the reconstruction of the prehistorical development of Slavic. PS segments are written in small capitals without asterisks.

${ }^{3}$ Leskien's subdivision of Class II verbs is no longer relevant to all of the modern Slavic languages and their dialects, and where rough equivalents of subclasses II.1, II.2.a, and II.2.b can be recognized, their membership often differs from the Old Church Slavonic state of affairs as a result of regional and local differences in development since Common Slavic. Hence some verbs that formerly belonged to one subclass have reflexes that exemplify different subclasses in the modern languages and their dialects. Such discrepancies have no apparent bearing on the questions of morphology which interests us here. 
Class IV, characterized by the present tense suffix - $i$-, has two subtypes, with aorist suffixes - - $^{-}$(mbněti 'think', Class IV.1) and - $i$ - (braniti 'defend', Class IV.2), respectively.

The abridged paradigms are given here to facilitate identification of the points of morphological similarity between the two classes.

\section{Figure 2. Leskien's Classes II and IV in Old Church Slavonic}

\begin{tabular}{|c|c|c|c|c|c|}
\hline & Class II.1 & Class II.2.a & Class II.2.b & Class IV.1 & Class IV.2 \\
\hline & $s$ & $m$ & $-t b$ & $b$ & 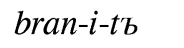 \\
\hline & sta-r & $m i-n$ & $-t b$ & $-t b$ & $-t b$ \\
\hline 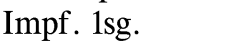 & $a x-b$ & $m i-n$ & $-\check{e}-a x-b$ & $m b n-\check{e}-c$ & $b r c$ \\
\hline & $s t$ & $m i-$ & dvig & $m b n-i$ & $b r c$ \\
\hline & & $m i-n$ & $d v i g$ & $m b n-\check{e}-t i$ & bra \\
\hline & & $m i-n$ & dvig & $m b n-\check{e}-x-$ & $-i-x-b$ \\
\hline & & $m i-n$ & dvig & $m b n-\check{e}-v-b$ & bra \\
\hline & sta-l-b & $m i-n$ & dvig-l-b & $m b n-\check{e}-l-b$ & bran-i-l-b \\
\hline Past pass. ptcpl. & $\longrightarrow$ & $m i-n o v-e n-b$ & $d v i z ̌-e n-\boldsymbol{s}$ & $m b n-\check{e} n-b$ & brań-en-b \\
\hline
\end{tabular}

\subsection{The infinitive suffix LCS $*_{-n} Q^{-}$}

In reconstructions of Common Slavic, the aorist and/or infinitive suffix OCS -no- of subtype II.2 verbs is traditionally projected directly into the past as LCS *-nQ-, although its nasal vowel is recognized as somewhat problematic: its presumed

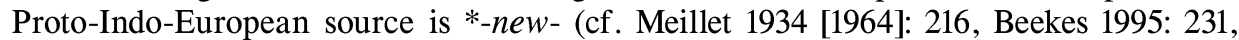
257). Most scholars follow Endzelin in pointing to the occasional lexical doublets in Slavic with $u$ and secondary $Q$ (such as OCS nuditi || nQditi force, PS NAUD-). Most of these have a syllable-initial nasal consonant to which the secondary nasalization can be ascribed, just as the suffix -no-. These well-known attested doublets might suggest the possible existence of an earlier LCS *-nu-. But most scholars refrain from speculating on the precise phonetic path from PIE *-new- to LCS *-no- (cf. Endzelin 1912: 370-372; Stang 1942: 56-57; Arumaa 1964: 131; Shevelov 1965: 320; Vaillant 1966: 230; Sławski 1974: 44; Lamprecht 1987: 104). ${ }^{4}$

(1) (a) P gnuśny 'disgusting', OCS gnušati gnošati sę, gnusbnъ gnosbnъ, Bg. gnusen gnъsen, M gnas; (b) P mudzić 'tarry', Sn. múditi, OCS muditi moditi, Bg. muden 'slow'; (c) P nudzić 'bore', nędza poverty, Sn. nuditi 'force', nuja noja need, OCS nuditi noditi 'force', nužda nožda force, Bg. nužda 'need', M nudi 'offer'; (d) P wnuk wnęk grandson, Sn. vnuk, Bg., M vnuk; (e) P chomato 'horsecollar', Sn. homột, SC hömut (o.) 'yoke', (st.) 'armful' (Altaic, possibly through Volga Bulgar or Hunnic, cf. Kazakh kamit, Mongol xomūD; Trubačev 1974-, s.v., Gołąb 1991: 402).

As we shall see, this last question is not immaterial to the account proposed below (section 2).

\footnotetext{
${ }^{4}$ Earlier, Miklosich had posited a change (CS) ${ }_{-}$naw- $>*_{-} n a-$, pointing to the prevocalic allomorph of the suffix in mi-nov-en-6, etc. (1875 [1926]: 429). Brugmann, on the other hand, proposed a morphological explanation for the nasal vowel in this suffix (Grundriss III/1: 322); cf. Ivšić 1970: 260-61.
} 
As we shall see, this last question is not immaterial to the account proposed below (section 2).

\subsection{Sn. d. sah-no-ti ${ }^{\text {"*t }}$ st. sah-ni-ti, d. sah-ni-ti ${ }^{\text {"*t }}$ st. sah-nu-ti}

Specialists in the dialectology of the South Slavic languages are familiar with the regional variation in the infinitive (and $l$-form) suffix exemplified in the heading of this section and acknowledge the variant Class II suffix in Sn. sah-ni-ti, SC d. sah-ni-ti as characteristic not only of standard Slovenian and most Slovenian dialects, but also of much of the western portion of the Croatian-Bosnian-Serbian language area.

As mentioned, the origin of the -ni- suffix has traditionally been considered unproblematic. Nahtigal's laconic statement, "in Slovenian, the Class II class marker - nQ- changed to - ni- by analogy with Class IV ..." (1961: 249) expresses the general consensus; cf. also Miklosich 1875 [1926]: 424, Ramovš 1952: 149, Bajec et al. 1973: 222. Vaillant did not subscribe to this standard explanation (see below), but he still considered it "not surprising that these languages remade the theme in - $n Q^{-}$(-nu-, $-n o-)$, isolated as it was from the present tense in -ne-" (1966: 259).

It is only recently that the relation of the "idiosyncratic" Western South Slavic $-n i$ - to Sn. d. $-n o-$ and SC st. $-n u$ - has been described and clarified in detail.

\subsection{The modern state of affairs}

A few years ago Rado Lenček surveyed the relevant dialectological literature in order to (i) determine the geographical distribution of -ni- verbs in Western South Slavic and (ii) shed light on the analogical processes through which Class II verbs (with LCS *-nQ-) might have metamorphosed into Class IV verbs (with Sn., SC d. $-n i-)$ in this area. Lenček's extremely valuable study (1984-1985) convincingly establishes two sets of findings from which significant conclusions can be drawn. First, his comprehensive survey of the relevant, published dialect research enabled Lenček to define the rather uneven geographical distribution of $-n i$ - verbs in Slovenian and Serbo-Croatian and to trace an isogloss that cuts across the Serbo-Croatian language territory and separates a western area with - ni- verbs from an eastern one that has only -nu-verbs. The isogloss is sketched in (2).

(2) The $-n i-\|-n u$ - isogloss runs from the Adriatic coast near Ston on Pelješac to the mouth of the river Neretva, up the Neretva past Mostar, across through Sarajevo to Žepče on the river Bosna, west to Banja Luka, down the river Vrbas to the Sava, up the Sava to its confluence with the Drina; then north bisecting Srem, crossing the Danube west of Novi Sad, on through Vojvodina, through northwestern and northern Bačka ..., across the river Tisa, eastward into northern and northeastern Banat (Lenček 1984-1985: 397-398).

The western territory this isogloss delimits includes the larger and smaller areas mentioned in (3).

(3) (a) Slovenian (with the exception of Rezija in the west and Eastern Styria and Prekmurje in the northeast, which have the regular reflex -no- of LCS *-no-); 
(b) a few peripheral kajkavian dialects which have had strong historical contacts with Slovenian (but not the main kajkavian territory, which has -nu-);

(c) ikavian štokavian and čakavian dialects in western Istria, in Gorski Kotar, the Lika basin, and Gacko Polje;

(d) the dialects of Senj and the Ravni Kotari south of Velebit;

(e) the islands Vrgada, Lastovo, Dugi Otok, Vis (but not Rab and Brač);

(f) western Bosnia and portions of western Hercegovina;

(g) western Slavonia, parts of Posavina and Podravina;

(h) western Srem, southern Baranja, western and northern Bačka, northern Banat;

(i) the outlier dialects of Gallipoli and Molise (Lenček 1985: 397).

Secondly, Lenček determined the geographical variation in the conjugation of $-n i$ - verbs in these areas. He identified six local or regional patterns on the basis of the formation of the present tense $\left(-n-e-\right.$ or $\left.-n-i_{-}\right)$and of the past passive participle (in -ń-en-, -ni-t-, or -nu-t-) (398). The main forms are displayed in figure 3.

\section{Figure 3. The conjugation of - ni- verbs in Serbo-Croatian}

Six regional and local patterns. Categories with variant forms are underscored.

\begin{tabular}{lllllll}
\hline & $(\mathrm{a})$ & $(\mathrm{b})$ & $(\mathrm{c})$ & $(\mathrm{d})$ & $(\mathrm{e})$ & $(\mathrm{f})$ \\
Inf. & $-n i-$ & $-n i-$ & $-n i-$ & $-n i-$ & $-n i-$ & $-n i-$ \\
$l$-form & $-n i-$ & $-n i-$ & $-n i-$ & $-n i-$ & $-n i-$ & $-n i-$ \\
Pres. & $-\underline{n-e-}$ & $-\underline{n-e-}$ & $-\underline{n-e-}$ & $-\underline{n-i-}$ & $-\underline{n-i-}$ & $-\underline{n-i-}-$ \\
Impv. & $-n-i_{-}-$ & $-n-i-$ & $-n-i-$ & $-n-i-$ & $-n-i-$ & $-n-i-$ \\
P. p. p. & $-\underline{n-e n-}$ & $-\underline{n i-t-}$ & $-\underline{n u-t-}$ & $\underline{-n-e n-}$ & $\underline{-n i-t-}$ & $\underline{-n u-t-}$ \\
\hline
\end{tabular}

The approximate geographical distribution of these conjugational patterns can be defined as in (4).

(4) Pattern (a): Slovenia and western Istria;

pattern (b): Gorski Kotar and Žumberak in historically mixed čakavian-štokavian-kajkavian dialects;

pattern (c): Lika, Senj, Dalmatia, western Bosnia, štokavian dialects in Posavina, most of Podravina, Srem, Bačka, Baranja, Banat;

patterns (d)-(f): štokavianized parts of old kajkavian and čakavian areas in Gorski Kotar, on Dugi Otok, in Posavina, and Slavonska Požega.

These findings enabled Lenček to draw two conclusions regarding the historical development of the $-n i$ - verbs.

The first conclusion is that there was no single analogical process by which the $-n i$ - verbs developed. It is reasonable to suppose that the most recent change was the change in the present tense from $-e$ - conjugation in patterns (a) - (c) to $-i$ - conjugation in patterns (d)-(f). This correlates with the geographical contiguity between patterns (d)-(f) and (b) and (c). Lenček assumes that the initial step in this process was a remaking of the past passive participle by analogy with the Class IV verbs (I will examine this assumption in section 2.1; contrast Vaillant 1966: 259), and he tentatively posits one conceivable course of development that would illustrate the remaining steps (400); see figure 4. 
Figure 4. The hypothetical analogical development of types (a) and (d) in figure 3

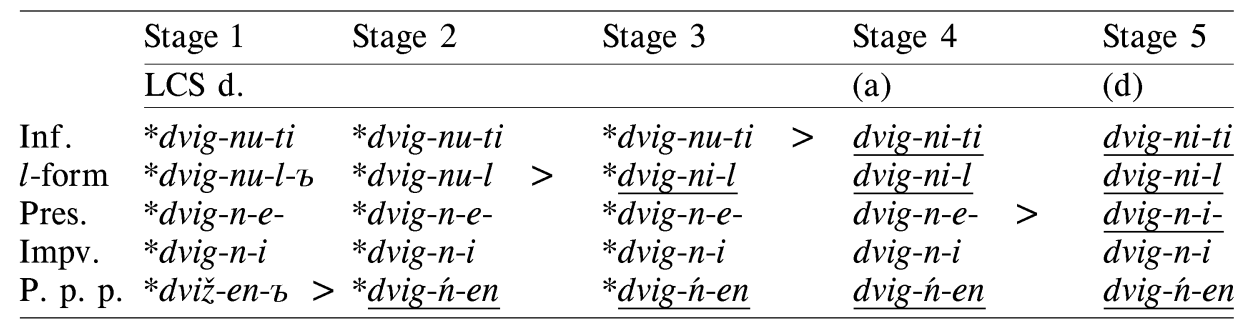

The second conclusion Lenček draws from his findings is that the -ni-patterns did not arise at first in a single center of innovation from which they subsequently diffused. He shows that the attested geographical distribution implies (i) that -ni- patterns arose in three focal areas - in the Eastern Alps (for Slovenian), west of the Neretva River (ikavian štokavian dialects) and somewhere in the northeastern part of the - $n i$ - territory (in ekavian štokavian dialects) - and (ii) that subsequent massive interaction, mixing, and fusion of earlier stages of related dialects spread the -niformations far beyond the areas where they originated (400).

\subsection{The putative change from LCS $*_{-n}$ - - to Sn., SC d. -ni-}

Lenček's study is very successful in establishing the geographical distribution of conjugation patterns with $-n i$ - and $-n u$ - in Western South Slavic, but its conclusions do not shed much light on the origin and development of these patterns.

Lenček admits that the sequence of changes suggested in figure 4 "does not seem to be clear at all." In fact it is hard to see any motivation for the crucial first step in the sequence, the new past passive participle formation of (a) and (d). Worse yet, whereas the chain of innovations in figure 4 is supposed to explain the development of patterns (a) and (d), there is no similar explanation for the other four -ni- verb patterns - (b) and (e), (c) and (f) (400). In these, the past passive participle was not remade according to the assumed analogy with Class IV verbs, and so when the present tense was supposedly assimilated to that of Class IV verbs-as in patterns (e) and (f) - the past passive participles in -ni-t and $-n u-t$, with $-t$ - rather than -en-, were actually morphological exceptions.

One would expect that if the Class IV participial formation was somehow important for the analogical development of -ni- forms in patterns (a) and (d), the absence of this crucial initial step and the retention of the formations in -ni-t and $-n u-t$ would have precluded the development of $-n i$ - forms in (b), (c), (e), and (f). Instead, Lenček's findings demonstrate that the change in the past passive participle was not a necessary precondition for the development of most of the -ni- patterns.

Vaillant, in his discussion of the Slovenian and Serbo-Croatian -ni- verbs, pointed out that the remodeling of the past passive participle is not a sufficient condition for the development of -ni- verbs either: kajkavian dialects form the past passive participles of Class II verbs exactly like the neighboring Slovenian and štokavian dialects, but they have the suffix $-n u$ - in the infinitive and $l$-form (1966: 259). Lenčeks findings - in particular the different conjugational patterns displayed in figure 
3 - point to an entirely different conclusion, which Lenček did not draw, namely, that the development of $-n i$ - forms in the infinitive and $l$-form of Class II verbs had nothing whatever to do with any changes in the past passive participle formation. This conclusion, which an unbiased observer would find directly indicated by the display in figure 3 is a basic premise for the exposition below. ${ }^{5}$

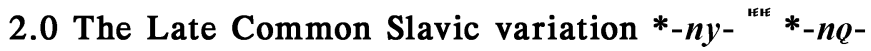

Sometimes it is useful to turn familiar things upside down in order to look at them from a fresh point of view. If we try to do this with the -no- $\|-n i-\| \mid-n u-$ variation, we discover that while it is difficult to imagine how or why LCS *-nomight have changed to - ni- in Western South Slavic, the opposite change would be rather easy to understand. There is a consensus that the nasalization in LCS *-no- is secondary; cf. section 0.2. And it is firmly established that LCS *Q results from a merger of several Proto-Slavic nasal diphthongs, PS -UN-, -ŪN-, -AN-, -ĀN- (where $\mathrm{N}$ represents PS $\mathrm{N}$ and $\mathrm{M}$ ) as in (5).

(5) LCS *gqba 'lip'; 'fungus' (PS GUMBĀ-, Li. gum̃bas excrescence), *dqti *d'bme 'blow' (PS DŪM-TI, DUM-Ā-M, Li. dùmti), *byti - *bede 'to be' inf., 1sg. future (PS BŪ-TẼI, BŪ-N-D-Ā-M, cf. Lat. mori-bundus 'dying'), *reka 'hand' (PS RANKĀ-, Li. ranka), *poto fetter (PS PĀNTA-, Li. pantis).

On the other hand, Sn. /i/ and SC /i/ are the regular reflexes of both LCS $* i$ (PS I, EI) and $* y$, (PS U) $)$. Hence Western South Slavic $-n i$ - and OCS -nQ- can be recon-

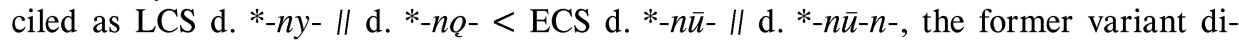
rectly representing a PS $-\mathrm{NU}-$, the latter showing the morphological and/or phonological change responsible for the "secondary nasalization."

The PS -NU- is the zero grade of the PIE *-new- that appears in the past passive participle and verbal noun (LCS mi-nov-en-b, mi-nov-en-bje), its length presumably analogical like that of the long alternant in Gk. deik-nu-mi, deik-nu-men 'show'; 1sg., 1pl. (cf. Beekes 1995: 231, 256).

The "secondary nasalization" may have originated as (i) an extension of the characteristic Class II present stem ${ }^{*}-n$ - to the aorist and/or infinitive stem. Or it may have originated as (ii) a progressive (left-to-right) nasalization of the vowel of

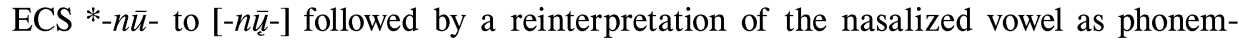
ically equivalent to ECS *ūn. Such a reinterpretation could occur with or without a prior morphological identification of the nasal feature of the vowel with the present stem $*-n$ -

As mentioned in section 0.1, there are other sporadic examples in the Slavic languages of progressive vowel nasalization in Late Common Slavic. These sporadic phonetic alterations produce by-forms with $u \| Q$ in different Slavic languages, and may well be younger than the monophthongization of oral diphthongs (ECS *au> $* \bar{u}$ ); the Altaic borrowing LCS *xomQt'b in (1)(e) corroborates this (cf. Gołąb 1991: 402; Trubačev has a different interpretation, see 1974, s.v.). By contrast, judging by

\footnotetext{
${ }^{5}$ Lenček's attempt to explicate the relation between the supposed changes in the past passive participle and the infinitive of Class II verbs points up the fact that the historical development of the participial formation (LCS $*-n o v-e n-z>-n u-t-\|-n-e n-\|-n-e n-$ ) is at least as poorly understood as that of the infinitive stem.
} 
the wide geographical distribution of the LCS d. *-nQ- suffix, the diversity LCS d. *-ny- II d. *-nQ- most likely goes back to the period before the Slavic Migrations, that is, before the ECS $* \bar{u}>* \bar{y}$ change and monophthongization of oral diphthongs,

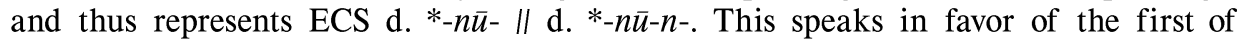
the alternative explanations for the diversity, mentioned as (i) above, the morphological innovation ECS $*-n \bar{u}->*_{-} n \bar{u}-n-$.

This account not only offers a simple alternative to the explanatory morass the conjugational patterns in figure 3 would lead us into if we assumed - $n i$ - forms are descended from LCS *-nQ- forms. The account provides a key to understanding the second of Lenček's findings, his conclusion that there must have been three distinct centers of innovation (cf. section 1.1): far from having to assume three parallel, independent, local innovations with inscrutable motivation, we can hypothesize a single archaism, ECS *-nu- or LCS d. *-ny-, going back to the Pre-Migration period of Common Slavic and transported to several localities in Western South Slavic at the time of the Migrations. But what makes this reconstruction especially attractive is the fact that it allows us to link the Western South Slavic -ni- forms to corresponding forms reflecting LCS *-ny- in several West Slavic areas, which indicate exactly the same interpretation.

\subsection{Upper Sorbian hasnyć "kit d. hasnuć}

In standard Upper Sorbian, Class II verbs have infinitives, preterites (aorists), and $l$-forms with -ny-, e.g., sta-ny-ć, sta-ny-ch, sta-ny-l 'become'; has-ny-ć, has-ny-ch, has-ny-l 'extinguish'. In the Bautzen and Kamenz regions, the infinitive ending written -nyć is pronounced [-nć].

Upper Sorbian has an old dialect difference involving verbs in $*_{-} n y-\| *_{-n} Q_{-}$. The northwestern (Catholic) Wittichenauer dialect has -ny- forms from the earliest attestations in the 1500s on. The dialects of the (Protestant) Bautzen and Löbau areas, by contrast, have $-n u$ - forms in the $1500 \mathrm{~s}$ and $1600 \mathrm{~s}$, but in texts from the $1700-1800$ s $-n u$ - forms gradually completely yield to $-n y$ - forms. This apparent morphic change, which generalizes -ny-spellings, probably to some extent was facilitated by the development of vowel reduction, which made the spellings with -ny-, which remain phonetically and phonemically motivated in the conservative northwestern dialects to this day, equally compatible with the more widespread pronunciation of the type [hasnć] both where this developed from hasnyć and where it developed from hasnuć extinguish; cf. Schuster-Šewc 1978: 447.

The early spelling differences in Sorbian and the modern testimony of the northwestern dialects of Upper Sorbian are unmistakable evidence of the older *-ny$\|{ }^{*}$-nQ- diversity. It has been claimed that purely phonetic changes produced the forms in -ny- in Upper Sorbian (thus Tkačenko 1966: 236). But this unsupported claim is baseless. The explanation for the *-ny- $\| *-n Q$ - diversity in the Upper Sorbian dialects is much more likely the same as in the case of Western South Slavic: some of the Slavs who colonized this area in the 500-600s spoke varieties of Common Slavic in which Class II verbs had the suffix *-ny-, whereas others used the suffix by-form *-nQ-. This is not to say that the clear-cut dialect difference attested in Upper Sorbian in the 1500s directly correlates with the areas that these two groups of settlers colonized in the Early Middle Ages. It is more reasonable to sup- 
pose that there was a $*_{-} n y-\sim *_{-} n Q$ - variation in many localities, probably for generations, perhaps even for centuries, before the tendency to establish uniform community norms resulted in the clear-cut areal distribution of $*$-ny- and $*_{-} n Q$ - reflexes that is known to us from the last five centuries. I will return to this sociolinguistic perspective below (section 3.1).

\subsection{Silesian d. kf'itnyć $^{\text {ktk }} k f^{\prime}$ itnuć}

In the Czech part of Upper Silesia there is a $*-n y-\| *_{-} n Q$ - isogloss that sets off the dialects around Jablunkov (P Jabłonków), in the upper Olše valley (P Olza, a right tributary of the upper Oder River), from the more northerly areas downstream. The northern dialects have -nu- forms (e.g., sta-nu-ć, sta-nu-l 'become', zamk-nu-ć, zamk-nu-l, zamk-nu-t-y 'shut, lock'), but south of the isogloss, which cuts across the Olše about $5 \mathrm{~km}$ up-river from Třinec, Class II verbs have forms

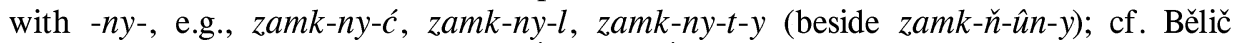
1972: 113; Basara 1975: 14, map 1 ( $\left.k f^{\prime} i t n u c ́, ~ k f^{\prime} i t n y c ́\right)$.

Neither Bělič nor Basara comments on the origin of the forms in -ny-. Bąk (1974: 14849) attempts to explain the krziknyć, siednyć sie, zamknyć forms he cites and speculates that their -ny- may contain the (denasalized) reflex of the virile gender plural $l$-form allomorph-in other words, that an earlier alternation zamknońc zamknou - zamknoua - zamknyli (corresponding to st. zamknać ... zamknęli) might have been leveled to zamknyć - zamknyu - zamknyua - zamknyli. However, this idea is contrary to the direction of leveling attested in all other dialects where the vowel alternation in the $l$-form is eliminated: it is always leveled in favor of a singular alternant, that is, an allomorph associated with the unmarked number, which is in accordance with Mańczak's laws of leveling (Mańczak 1957-1958, 1963). Besides, this attempt at an explanation ignores the past passive participle, which has lexicalized formations in -ny-t- in these dialects (e.g., o-puch-ny-t-y 'bloated'), with no trace of the nasalization Back posits (which would have been reflected in a shape *-nont-).

What is more, Bak's hypothesis leaves unconsidered the geographical perspective, and the local character of this dialect feature, unexplained: the supposed innovation (if it were a plausible analogical change) could have occurred anywhere at all in the Polish language territory; but its supposed results are attested only in dialects spoken, until recently, in one of the most isolated parts of Silesia, in localities where it would not be surprising at all to find an archaism preserved.

There is no reason not to take these -ny-forms at face value. If we do, we can identify one more area that was apparently colonized (in part) by a group or groups of speakers of a Common Slavic $*_{-} n y$ - dialect.

\subsection{Polabian vataknĕt ${ }^{\text {Hнt }}$ vataknot}

Despite the small number of Class II verbs in the corpus of Polabian that has come down to us, there is evidence of two distinct shapes of the infinitive suffix, one reflecting LCS $*-n y$-, the other, LCS $*-n Q^{-}$. There is a handful of Class II verbs with infinitives in $*_{-}$- $Q$ - $t i$. They are cited in (6), each infinitive in a typical spelling form accompanied by the phonemic interpretation of Olesch (1983-1984, s.vv.) and by the corresponding Late Common Slavic reconstruction. 
(6) (a) Saddargnûnt 'ripple (flax)': sa-dargnǫt, LCS *słbdbrgnoti; (b) Tangnunt 'draw, stretch', Wastangnunt 'pull up': vas-tagnot, LCS *vbs-tegnoti; (c) Tweiggenunt 'raise': dvaignot, LCS *dvignoti; (d) Wattakenûnt 'put in', Wastakenûnt 'put up': va-, vas-taknot, LCS *vb-, vъs-tbknoti; (e) Wamakenûnt 'lock up', Witmakenûnt 'unlock': va-, vit-maknǫt, LCS *vb-, *otъ-mbknǫti; (f) Wirggenûnt 'throw': virgnot, LCS *vbrgnoti.

Two of these verbs are attested with variant infinitive forms, (d) Watóakent 'put in' and (f) Würggent 'throw', and one more verb is attested only with such an infinitive, (g) Wáykent (Waykent, Waýkent) 'learn'. These forms are normalized vataknět, virgnĕt, vaiknĕt (Polański and Sehnert 1967, s.vv.; Olesch 1983-1984, s.vv.). Since there is a fair amount of spelling variation in the corpus, it is important to mention that these variant forms are attested in the original manuscript draft of Christian Hennig von Jessen's Vocabularium and hence cannot easily be dismissed as copying mistakes. They have to be viewed, rather, as an indication of dialect diversity among the speakers from whom Hennig von Jessen collected his data.

Olesch reconstructs the three variant Class II infinitives as LCS *vbtrkniti, *vbrgniti, *vykniti (in agreement with Polański and Sehnert 1967, s.vv.). However, the

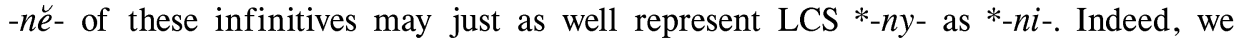
can now argue that for comparative reasons $*_{-} n y$ - is to be preferred. This reconstruction does not require an ad hoc analogical explanation of dubious plausibility (along the lines of the hopeless attempts cited in sections 2.1, 2.2, and 2.3). And it allows the apparent Polabian dialect diversity in the Class II suffix -nĕ- $\|-n Q$ - to be tied in very simply with the other examples of the Late Common Slavic suffix variation $*_{-} n y-\| *_{-} n Q^{-}$. It is evidence that some of the Slavic settlers who colonized the Lower Elbe area continued the same linguistic traditions as settlers in Upper Silesia, in Upper Lusatia, in the Eastern Alps, and in parts of Illyricum-traditions that very likely went back to a single circumscribed area in the Pre-Migration Common Slavic homeland.

\subsection{The Slavic colonization of the west}

If you plot the areas that have the archaic LCS *-ny-variant on a map of the Slavic-speaking territories, say, in the $800 \mathrm{~s}$, their distribution along the western margin of the Slavic world will look very much like an example of peripheral relic areas left unaffected by an otherwise general change. But we know these are not relic areas. They were settled by Slavs only during the Migrations, and this archaism must have been brought to the locations where we find it in modern times by the waves of Slavic settlers who colonized southern and central Europe in the 400-700s.

Until recently such a geographical distribution of a Slavic linguistic archaism would have been difficult to understand (cf. Schuster-Šewc 1978: 447). But the gradual accumulation of archaeological data from the Early Middle Ages, as well as advances in their interpretation, have now made it possible to progress from the definition of areas colonized by the Slavs to the identification of the major routes by which Slavic cultural and linguistic traditions gradually spread across the Continent during this period. The map in figure 5 shows, perhaps not surprisingly, the importance for the Slavic Migrations of the ancient system of roads, which throughout Europe predominantly followed the courses of the rivers. The gradual spread of the 
different Slavic house types plotted in figure 2 allows us to trace the Migration routes up the river Danube, upstream along its tributaries - the Sava and the Drava river systems - into Pannonia and Noricum, up the Morava to Upper Silesia; across the Bohemian Basin and through the Elbe River Gorge to the northern watershed of the Ore Mountains in Upper Lusatia; and beyond, down the Elbe to the eastern border regions of the later principality of Hannover, along the banks of the Lower Elbe.

Figure 5. Slavic settlement routes in the 400-700s

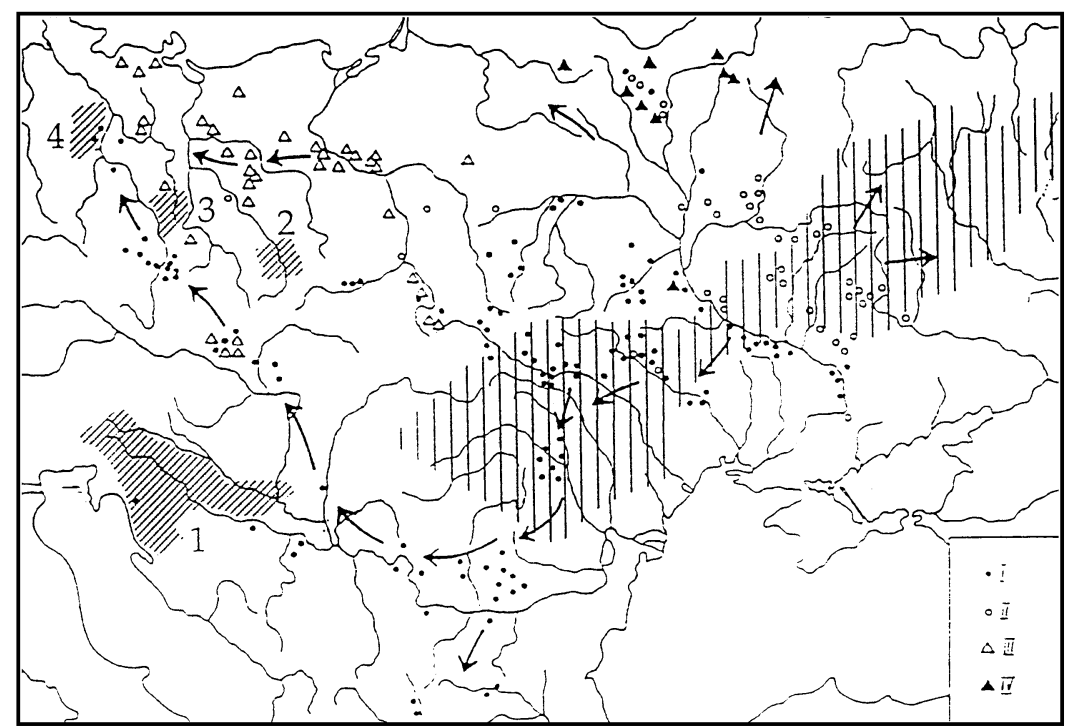

Legend: - Semisubterranean houses with stoves. $\circ$ Semisubterranean houses with open hearths. $\Delta$ Other types of Slavic dwellings with open hearths. $\Delta$ Above-ground houses. Cf. Baran 1990: 359. Vertical hatching marks the parkland transition between the forest zone and the steppe. The areas numbered 1-4 are discussed in sections $1.0,2.1,2.2$, and 2.3 , respectively.

As it turns out, the geographical distribution of the LCS *-ny-variant in the four areas indicated on the map constitutes a remarkable linguistic corroboration of the archaeological record. One can trace the Migration routes back mentally, across the continental divide into Bohemia and Moravia, down the Danube to its lower course, and then northward, into the presumable Slavic homeland, to that (peripheral?) Common Slavic dialect area in which the change ECS $*-n \bar{u}->*-n \bar{u}-n$ - had not occurred when the Migrations began. Most likely this was somewhere in the present-day East Slavic language area, probably a relatively small region long since repopulated with speakers of $*$-nQ- dialects.

\subsection{A sociolinguistic view of the $*_{-} n y-\sim *_{-} n Q^{-}$variation}

It is reasonable, in such a mental experiment, to surmise that the colonists who hailed from this Common Slavic *-nu- area - and their descendants as well, in some 
locations, for generations - perceived the LCS *-ny- variant as an index of their group identity. Conceivably, in the Slavic Migrations, *-ny- forms were transported to many other places than the four regions we know of now along the same and other routes. In most localities where there was a $*_{-} n y-\sim *_{-} n Q_{-}$variation at the end of the period of territorial expansion, the *-ny-forms were eliminated in favor of $*_{-} n Q$ - forms. Similarly we can suppose that $*_{-} n Q$ - forms at one time were known also in the communities of the four regions where $*_{-} n y$ - reflexes are historically attested. But on the whole a consistent usage developed everywhere in the Slavic lands during the Middle Ages as smaller and larger communities little by little established uniform local and regional norms of usage. Although Polabian gives evidence of both the variants, this is not evidence of a synchronic *-ny- $*_{-} n Q_{-}$ variation in eighteenth century Polabian, for the forms probably belonged to different local dialects. This is the case as well in the twentieth century Czech dialects of Upper Silesia. The picture appears different in Upper Sorbian, where our written documentation testifies to competing norms in the 1700-1800s. But perhaps this was a relatively new situation, brought about by the greater mobility generated by the social upheavals of the 1600s. If so, the increased contact among Sorbian dialects at the time would naturally motivate some leveling of previously established differences and in the process perhaps favor the attested generalization of $-n y$ forms.

The Serbo-Croatian data summarized in figure 3 should surely be interpreted as the final stage in such a process. The dialects with pattern (c) are likely original $-n u$ - dialects that have adopted $-n i$ - in the infinitive and $l$-form. It is very characteristic that these dialects preserve $-n u$ - in the past passive participles. These verbal adjectives are much more likely to be lexicalized and hence to preserve morphological archaisms, than are the infinitive and the finite $l$-forms. ${ }^{6}$ This is particularly clear from the dialects characterized under (f); they have taken the final step of aligning the present tense with the Class IV conjugation, but they still retain the lexicalized, morphologically exceptional past passive participles in -nu-. These details in the Serbo-Croatian data, which remain unexplained in the analogical account sketched by Lenček (cf. section 2.3) should be emphasized before we leave this topic. They show that the traditional theory, in trying to explain the Slovenian and Serbo-Croatian $-n i$ - verbs as originating in a remodeling of the past passive participle, erred not only by looking for an analogical explanation where none was called for, but also by assuming relations of foundation in verbal paradigms which run counter to our experience with morphological change: participles are not usually 'leading forms', or 'formes de fondation' in Kuryłowicz's terminology (1949 [1960]), but on the contrary, more likely than finite forms and infinitives to be lexicalized and hence to exemplify earlier formation rules.

\footnotetext{
${ }^{6}$ At the same time, as separate lexemes, deverbal adjectives can be borrowed without any adjustment to the productive verbal morphology of the borrowing language. It is notable that standard Slovenian has a few deverbal adjectives with -nu-, minuli 'past', poginuli 'deceased' (contrast miniti - minil 'pass', poginiti - poginil 'perish'). These and some other lexemes with $u$ for LCS $*_{Q}$ are also found in Slovenian dialects, including dialects with the -no- reflex of the Class II suffix. Ramovš considers a number of possible explanations for these, including borrowing from Serbo-Croatian (1936: 179-180).
} 


\subsection{Final outlook}

A generation ago Trubačev observed that the Sorbian languages differ from their West Slavic neighbors and in significant respects have more in common with the Slavic south and east. The separateness of Upper and Lower Sorbian is observable, for example, in their specific Common Slavic lexical archaisms (Trubačev 1963), in their inherited craft terminology (Trubačev 1966), and in the striking absence in these languages of the narrowly West Slavic borrowings from Iranian, undoubtedly dating from the Common Slavic period, which are found in the Lechitic and Slovak-Czech regions (Trubačev 1967). Trubačev concluded that the Sorbian languages are basically southern or eastern, and that the superficial features by which they resemble Lechitic and Slovak-Czech result from what he called their "secondary occidentalization."

Until recently it was difficult to imagine by what routes eastern or southern Slavs could have reached Lusatia to become the linguistic ancestors of the Sorbs, independently of the colonization of the Slovak-Czech and Lechitic lands, and Trubačev's theory did not attract many followers. But the synthesis presented in Baran 1990 has made it clear how this was feasible and has provided the necessary non-linguistic grounding for Trubačev's bold hypothesis. The peculiar relationship between Slovenian, Silesian Czech dialects, Upper Sorbian, and Polabian that is reflected in the data analysed in this study may not be as unique as it may seem at first blush. It certainly suggests that we should look more closely at those linguistic relations among the Slavs that correspond to the routes by which they settled the west.

\section{References}

Arumaa, Peeter. 1964. Urslavische Grammatik, I. Einleitung, Lautlehre. Heidelberg: Carl Winter Universitätsverlag.

Bajec, Anton, Rudolf Kolarič, and Mirko Rupel. 1973. Slovenska slovnica. Ljubljana: Državna založba Slovenije.

Baran, Vladimir Danilovič (ed.). 1990. Slavjane jugovostočnoj Evropy v predgosudarstvennyj period. Kiev: Naukova dumka.

Basara, Jerzy. 1975. Stownictwo polskich gwar Ślaska na terenie Czechostowacji (Polska Akademia Nauk. Prace Instytutu Języka Polskiego 1). Wroclaw/Warsaw/Cracow/Gdańsk: Ossolineum.

Bąk, Stanisław. 1974. Mowa polska na Ślasku (Opolskie Towarzystwo Przyjaciół Nauk. Wydział II jezyka i literatury). Wroclaw/Warsaw/Crakow/Gdańsk: Ossolineum.

Beekes, Robert S. P. 1995. Comparative Indo-European Linguistics. An Introduction. Amsterdam: John Benjamins.

Bělič, Jaromír. 1972. Nástin české dialektologie. Prague: Státní pedagogické nakladatelství.

Endzelin, Jan. 1912. O proisxoždenii praslavjanskix infinitivov na -noti. Russkij filologičeskij vestnik 4.370-372 Repub. in his Darbu izlase, II, 466-68. Riga: Izdevniecība Zinātne, 1974. 
Gołąb, Zbigniew. 1990. The Origins of the Slavs. A Linguist's View. Columbus, Ohio: Slavica Publishers.

Ivšić, Stjepan. 1970. Slavenska poredbena gramatika, ed. Josip Vrana and Radoslav Katičić. Zagreb: Školska knjiga.

Kuryłowicz, Jerzy. 1949 [1960]. La nature des lois dits analogiques, Acta Linguistica Hafniensia 5.15-37. Republished in his Esquisses linguistiques (Polska Akademia Nauk. Prace językoznawcze 19), 66-86. Wroclaw/Cracow: Ossolineum.

Lamprecht, Arnošt. 1987. Praslovanština. Brno: Univerzita J. E. Purkyně.

Lenček, Rado. 1984-1985. Is there a -ni-: -ne- isogloss in the South Slavic speech area? Zbornik Matice srpske za filologiju $i$ lingvistiku (Nova serija) 27/28.395-403.

Leskien, August. 1910 [1990]. Handbuch der altbulgarischen (altkirchenslavischen) Sprache. Grammatik - Texte - Glossar (10., von Johannes Schröpfer mit Verbesserungen und Ergänzungen versehene Auflage) [Fifth edition 1910]. Heidelberg: Carl Winter, Universitätsverlag.

Mańczak, Witold. 1957-1958. Tendances générales des changements analogiques, Lingua 7.298-325, 387-420.

- -. 1963. Tendances générales du développement morphologique, Lingua 12.19-38.

Meillet, Antoine. 1937 [1964]. Introduction à l'étude comparative des langues indo-européennes [Eighth edition, prepared by Émile Benveniste]. Repub. with a preface by George C. Buck. University, Ala.: University of Alabama Press.

Miklosich, Franz. 1875 [1926]. Vergleichende Grammatik der slavischen Sprachen, II. Stammbildungslehre. Manulneudruck der Erstausgabe von 1975. Heidelberg: Carl Winters Universitätsbuchhandlung.

Nahtigal, Rajko. 1961. Die slavischen Sprachen. Abriß der vergleichenden Grammatik [Translated by Joseph Schütz from Slovanski jeziki, Ljubljana 1952]. Wiesbaden: Otto Harrassowitz.

Olesch, Reinhold. 1983-1984. Thesaurus linguæ dravænopolabicæ, I-III (= Slavistische Forschungen, 42/I-III). Cologne/Vienna: Böhlau Verlag.

Polański, Kazimierz and James Allen Sehnert. 1967. Polabian-English Dictionary. The Hague/Paris: Mouton.

Priestly, Thomas M. S. 1993. Slovene, The Slavonic Languages, ed. Bernard Comrie and Greville G. Corbett, 388-454. London/New York: Routledge.

Ramovš, Fran. 1936. Kratka zgodovina slovenskega jezika I. Ljubljana: Akademska založba.

- -. 1952. Morfologija slovenskega jezika. Ljubljana: Univerzitetna študijska komisija.

Schuster-Šewc, Hinc. 1978. Zur Bedeutung des Sorbischen und Slowenischen für die slawische historisch-vergleichende Sprachforschung, Slovansko jezikoslovje. Nahtigalov zbornik ob stoletnici rojstva, ed. by Franc Jakopin, 433-451. Ljubljana: Univerza v Ljubljani. 
Shevelov, George Y. 1965. A Prehistory of Slavic. The Historical Phonology of Common Slavic. New York: Columbia University Press.

Sławski, Franciszek. 1974. Zarys słowotwórstwa prasłowiańskiego, Stownik prastowiański, I. AB, 43-141. Wroclaw/Warsaw/Cracow/Gdańsk: Wydawnictwo Polskiej Akademii Nauk.

Stang, Christian S. 1942. Das slavische und baltische Verbum (= Skrifter utgitt av Det Norske Videnskaps-Akademi, II. Hist.-Filos. Klasse, 1). Oslo: Jacob Dybwad.

Tkačenko, O. B. 1966. Dijeslovo, Vstup do porivnjalno-istoryčnoho vyvčennja slov'jans'kyx mov, ed. O. S. Melnyčuk, 214-255. Kiev: Naukova dumka.

Trubačev, Oleg Nikolaevič. 1963. O praslavjanskix leksičeskix dialektizmov serbo-lužickix jazykov, Serbo-lužickij lingvističeskij sbornik, ed. L. È. Kalnyn’, 154-172. Moscow: Izdatel'stvo Akademii Nauk.

- -. 1966. Remeslennaja terminologija v slavjanskix jazykax (ètimologija $i$ opyt gruppovoj rekonstrukcii). Moscow: Nauka.

- -. 1967. Iz slavjano-iranskix leksičeskix otnošenij, Ėtimologija 1965, 381.

- -. 1974-. Ėtimologičeskij slovar' slavjanskix jazykov. Praslavjanskij leksičeskij fond, 1. Moscow: Nauka.

Vaillant, André. 1966. Grammaire comparée des langues slaves, III. Le verbe, 1-2. Paris: Klincksieck.

- -. 1964. Manuel du vieux slave. Tome 1. Grammaire. Paris: Institut des études slaves.

Prispelo septembra 1997, sprejeto junija 1998

Received September 1997, accepted June 1998

\section{O zahodnojužnoslovanskem nasprotju sln. sah-ni-ti /l sh. sah-nu-ti}

Prispevek na novo ocenjuje tradicionalno razlago za »svojevrsten razvoj« praslovanskih glagolov II. razreda $\mathrm{z}$ aoristno in/ali nedoločniško pripono -no-, ki so izpričani v scsl. kot sbxnoti 'sahniti', pol. schnać, rus. soxnut', sh. sahnuti, vendar v sln. kot sahniti. Običajno se ta posebni razvoj v slovenščini razlaga kot preprosta analogija z glagoli IV. razreda, npr. braniti. V toku te nove ocene avtor kaže, da se "svojevrsten razvoj< - takoj ko je na novo prikazan - ujema s podatki iz drugih slovanskih jezikov. Namesto da bi izhajal iz domneve, da je pripona -ni- izpodrinila $-n Q^{-}$, avtor dokazuje, da je smiselno izhajati iz praslovanske razlike $-n Q-\| /-n y-(<$ zgodnjepraslovansko inovativno ${ }^{*}-n \bar{u}-n-\|$ arhaično $\left.{ }^{*}-n \bar{u}-\right)$, ki je po vsej verjetnosti iz časa pred slovanskimi selitvami. Ti različni obliki sta lahko povzročili variacijo, ki je izpričana v sodobnih slovanskih jezikih. Variacija je potovala s Slovani, ki so kolonizirali zahodnojužnoslovansko in zahodnoslovansko ozemlje med 5. in 8. stoletjem; zaradi variacije je $\mathrm{v}$ naslednjih stoletjih nastalo tekmovanje med dvema različnima oblikama. Ti rezultati se dobro ujemajo $\mathrm{z}$ rezultati novejših raziskav, ki so določile poglavitne smeri selitve Slovanov, ki so bile po Donavi v Panonijo in Norik, navzgor po Moravi do zgornje Šlezije, prek češke nižine in po soteski Labe do Češkega rudogorja v Zgornji Lužici; nadalje navzdol po Labi do vzhodne meje kasnejše kneže- 
vine Hannover in po bregovih spodnje Labe. Miselno potujoč po teh poteh v obratni smeri, avtor predlaga, da je zgodnjepraslovanska oblika *-nū- bila morda značilna za nekdanja narečja na ozemlju današnjih vzhodnih Slovanov. To verjetno sorazmerno majhno področje je bilo že zdavnaj na novo poseljeno $\mathrm{z}$ govorci narečij $\mathrm{z}$ obliko $*-n Q-$.

\section{The Western South Slavic Contrast Sn. sah-ni-ti // SC sah-nu-ti}

The paper reexamines the traditional explanation for the "idiosyncratic development" of the Common Slavic Class II verbs with the aorist and/or infinitive suffix -nQ-, attested in OCS sbxnoti 'dry', P schnać, R soxnut', SC sahnuti, but in Slovenian as sahniti. The peculiarity that gave rise to this development in Slovenian is generally thought to be simple analogy with the Class IV verbs, e.g., braniti 'defend' In the course of this reexamination, the author shows how the "idiosyncratic development," once restated, fits in with data from other Slavic languages. Rather than proceeding from the assumption that the -nQ- type was replaced by -ni-, the author demonstrates that it is reasonable to depart from a Common Slavic dialect

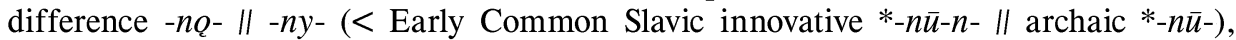
which probably had its origin in the period before the Slavic Migrations. These by-forms could thus have given rise to the variation that is found in the modern Slavic dialects. This variation was transported with the Slavs who colonized the Western South Slavic and West Slavic territories in the 400-700s and in turn gave rise to sociolinguistic competition between the alternatives in the following centuries. These findings are shown to correlate well with recent advances in the identification of the major routes of migration taken by the Slavs, which progressed up the Danube, into Pannonia and Noricum, up the Morava to Upper Silesia, across the Bohemian Basin and through the Elbe River Gorge to the Ore Mountains in Upper Lusatia; then beyond, down the Elbe to the eastern border regions of the later principality of Hannover and along the banks of the lower Elbe. Working back from these

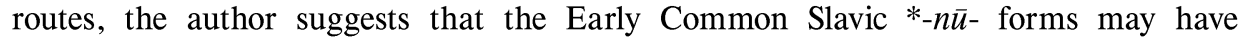
characterized dialects somewhere in the present-day East Slavic language area, probably a relatively small region long since repopulated with speakers of $*-n Q$ - dialects. 